László Kákai

\title{
Trailing back \\ from quasi decentralisation to centralisation. Municipal reform in Hungary ${ }^{1}$
}

\section{Introduction}

During the latest decades, the activity of municipalities, state finances, the current budget and within this, especially the provision of local public services have essentially been affected by the economic theories that follow, replace or combine with each other and one of the basic questions of which has concerned the role played by the state in the economy and public services ${ }^{2}$.

The theory of financial federalism, which has been thriving for the latest fifty years, considerably helps the scientific understanding of the centralization-decentralization process ${ }^{3}$.

Mainly in the Anglo-Saxon countries, the examination of "local governance” and "local politics" after World War II produced considerable results in the '50s, providing by this the justification of researching local politics ${ }^{4}$. Opposing to this, the terms "local governance”, „local state” and „local politics” were only „byproducts" of the state and power theories on the European continent. Their role and importance appeared as topics to be examined independently only in the '70s and ' $80 \mathrm{~s}^{5}$. The names "local state" and „local governance" were more and more often used after the mid of the " 70 s when local governance had started to be

1 Research for this paper was supported by the following grant: EFOP-3.6.3-VEKOP-16-201700007 Young researchers from talented students - Fostering scientific careers in higher education.

2 I. Finta, A helyi-területi szintü közigazgatási szervezetek gazdaságirányítási, támogatás-fejlesztési funkcióinak jogszabályi háttere, [in:] Versenyképesség és igazgatás (tanulmányok a regionális versenyképesség igazgatási feltételeirő, ed. K. I. Pálné, Pécs 2004, p. 35-56.

R. A. Musgrave, The Theory of Public Finance, New York 1959.

R. Dahl, Who Governs? Democracy and Power in an American City, New Haven 1961.

P. Saunders, Urban Politics: A Sociological Interpretation Harmondsworth 1980; J. Dearlove, The Reorganisation of British Local Government, Cambridge 1979; P. Dunleavy, Urban Political Analysis, London 1980. 
considered as the integral part of a globalizing political system. The term „local government" basically appeared in opposition to the traditional „public administration" approach (which focused exclusively at the organizations and institutions of local governance). Contrary to this, the new label covered the wider (political, economic and social) context of the operation of local governments, as well.

The public administration and/or state and municipal reforms implemented in Europe during the latest decades can basically be grouped according to the often contradictory responses given to the questions about the re-definition of the role of the state and the economic efficiency of public services ${ }^{6}$.

The central element in the focus of initial theories was decentralization ${ }^{7}$ that was the only factor capable of limiting the centralization of power owing to the fact that local governments could provide more flexible and more controllable public services that meet actual consumer preferences ${ }^{8}$. Later, the theorems of information economics originating in the science of economics got built in the frameworks of fiscal federalism as new elements, owing to which the stress shifted from the effectiveness of the financial relations between governments to local income and resource generation ${ }^{9}$. At this time, the mere provision of public services was more and more replaced by the local economy organizing and development role of the municipalities. These theoretical trends dominated the '70s and the ' 80 s, as well, and several trends dealing with local politics were arising, like the localist approach or the new theory of better or community choice but we can also mention the thesis of the dual state or the theory of relations between the local state and society that all together provided the theoretical framework of the almost continuous ${ }^{10}$ transformation ${ }^{11}$ of the local municipal systems.

International public administration efforts took on a new direction at the beginning of the 2000s. The reason for this was the series of the appearance of mainly financial crises that finally culminated in the global financial crisis of 2008. The reason for the change of attitudes was that smaller and cheaper states that had come to life were unable to provide effective solutions for the problems. In this case, a small and cheap state also meant a weak one. As for governance-like,

6 L. Kákai, Kik vagyunk mi? Civil szervezetek Magyarországon, Pécs 2009, p. 134-135.

7 In Europe, the term subsidiarity is rather used instead of federation. Á. Szalai, Fiskális Föderalizmus. Áttekintés, „Közgazdasági Szemle” 2002, no. 5, p. 424.

8 Ch. M. Tiebout, A pure theory of fiscal decentralization, „The Journal of Political Economy” 1956, no. 64, p. 416-424; W. E. Oates, Toward a second-generations theory of fiscal federalism, „International Tax and Public Finance” 2005, no. 12, p. 349-373.

9 A. Vígvári, Atipikus önkormányzati eladósodás Magyarországon, „Közgazdasági Szemle” 2009, no. $7-8$, p. 709 .

10 From the '60s until our days.

11 L. Kákai, Önkormányzat és lakosság viszonya, avagy bizalom vagy bizalmatlanság, [in:] Közigazgatás és az emberek, ed. F. Csefkó, „Pécsi Közigazgatás-Tudományi Közlemények 5. A Jövő Közigazgatásáért Alapítvány”, Pécs 2013, p. 153-170. 
"hybrid" state systems, the main trend of criticism applied to the lack of transparency and democratic legitimacy ${ }^{12}$. Consequently, the so-called neo-Weberian state concept stressed: the enhancement of state functions as compared to the past, the requirement of providing quality services in a professional way, the extension of citizen and public administration consultations and the spread of result-based attitudes. „Returning” to Weberian heritage practically emphasised the re-strengthening of state functions and the importance of regulative and control functions of public administration, as well as of public service itself. Although the model cannot be taken as a new paradigm of governance, in many countries, it has brought about significant shifts, pushing the prestige and field of prevalence of New Public Management into the background ${ }^{13}$.

Perhaps it is for this reason that almost all governments coming to power in the consecutive parliamentary cycles felt it was their duty to transform or modify public administration. During this process, very similar questions and directions of change appeared, such as the requirement of effectiveness, cost-efficiency and success of public administration or the promise of implementing a welfare state ${ }^{14}$.

In Central Europe, so also in Hungary, after the collapse of state socialism and during the formation of the democratic structures, decentralisation primarily meant the distribution of public service provision in terms of locality and organisational levels and the adequate arrangement of financial relations.

In Hungary, there were two options in order to permit durable maintenance of the balanced regulatory result ${ }^{15}$. The first was the option of the economies of scale which emphasises the differentiation of tasks between units of local governments of different sizes. The other solution was that smaller municipalities provide the service functions exceeding their order of magnitude within the frameworks of consciously organised integration entities. Practically, these were the two ways by which the municipal structure, which was apt to give a framework to the domestic financial, historical and settlement structure challenges and endowments, had to be found.

From our perspective, the course that the municipality system has run within the relation system of central power since the transition era is a core issue. How

12 Handbook of Public Policy, eds. G. B. Peters, J. Pierre, London 2006.

13 W. Dreschler, R. Kattel, Towards the Neo-Weberian State? Perhaps, but Certainly Adieu, NPM!, „The NISPAcee Journal of Public Administration and Policy” 2009, no. 2, p. 95-101.

14 The main issues and content of the reform cycles are properly summarised by Krisztián Kádár's paper, introducing the main public administration ideas and output of certain governmental eras K. Kádár, Reformkonyha a magyar közigazgatásban, [in:] A közigazgatási reform új perspektívái, eds. A. Ágh, I. Somogyvári, Budapest 2006, p. 296-319.

15 Integration of the exercise of functions, both from the point of view of the organisation of public administration and in terms of the politics of public administration. B. R. Weingast, Second generation fiscal federalism: Implications for decentralised democratic governance and economic development, Discussion Draft, Hoover Institution, Stanford 2009. 
did the relationships of the centre and the municipalities change from the transition until 2010, when the government considerably transformed this system of relations and even the municipality level itself (in a historical way and at a scale similar to that implemented at the dawn of the transition?) Thus, in this study, the interrelation of centralisation and decentralisation is basically determined by the question of which public services were provided at the central or governmental level and which ones were implemented at the regional or local level?

\section{Frameworks of public administration structures}

It is very difficult to categorise countries and governmental systems according to the level of decentralisation or the model they adopt in the geographical distribution of power. Geographical division highly depends on the size of the states and their population but first and foremost, on the political-ideological objectives and system of conditions of social organisation and direction ${ }^{16}$. Concerning their constitutional legal status, tasks, authority and organisational system, municipal systems show a very diverse picture in Europe. In terms of the constitutional position and role of the local-territorial municipality and the central-local relation systems, international literature distinguishes three big country group ${ }^{17}$ of developed democracies ${ }^{18}$ : the French or Napoleonic, the Anglo-Saxon and the mixed or continental model. John Loughlin $(2001)^{19}$ provides further precision of this methodological framework by dividing and distinguishing between the systems built on German and Scandinavian traditions. According to this classification, Hungary created her state structure by mixing French and German traditions. The creation of the Hungarian constitution and governmental structure was highly influenced by the public administration and legal structure of the German Federal Republic. At the same time, concerning the structure of the public administration-organisational system, Hungary's constitution and governmental system was not federal; rather, it was uniform or Unitarian ${ }^{20}$. Nevertheless, the act

16 Z. Hajdú, A magyar megyerendszer történeti, területi fejlödésének sajátosságai, [in:] A rendszerváltás és a megyék, eds. Z. Agg, K. I. Pálné, Veszprém 1994, p. 7-29.

17 Local Government and Urban Affairs in International Perspective, ed. J. J. Hesse, Baden-Baden 1991.

18 It is important to emphasise the fact that this distribution is not only apt to describe territorial structures.

19 J. Loughlin, Subnational Democracy in the European Union. Challenges and Opportunities, Oxford 2001.

20 This means that the constitution acknowledges the right of self-governance of the settlements, however, it does not give any content details, not even in terms of municipal tasks. This model assures a narrower scope for local authorities (e.g. the operation of municipalities can only be 
on self-governance, passed in 1990, established a strong and decentralised system of territorial municipalities ${ }^{21}$ that had the following main features ${ }^{22}$ :

- Decentralisation without enforcing subsidiarity;

- Despite the constitutional status, maintaining a strongly centralised system through the allocation of state-controlled resources;

- Adopting Napoleonic traditions, i.e., one settlement, one local government principle, which resulted in a fragmented system of local governments.

Asserting the above characteristics seemed easier because in Hungary municipal decentralisation had no strong traditions. Forceful centralisation was dominant not only in the state socialist era between 1950 and 1990 but in most of the earlier periods of state development as well.

Between 1990 and 2011, in a practically unique way, the Hungarian municipal system assured a very wide range of rights for local governments and the institution of local governance was entrenched by a so-called "cardinal" act (demanding qualified majority), along with legal regulations put down in the constitution. These laws strengthened the autonomy and sovereignty of local authorities (within domestic legal frameworks). The only supremacy above their activities was legal supervision but even that was enforceable only with juridical approval. In terms of the legal conditions determined by the constitution and the act on local governments passed in 1990, the local municipalities (that were either settlement or regional authorities) had a wide range of obligations in service provision (obligatory tasks), many possibilities (voluntarily undertaken tasks and entrepreneurial activities) and a high level of financial independence (possibilities of having own incomes, normative central financing, being provided with properties or the possibility of starting business activities).

I wish to present the operation of the system and the strengthening of its internal contradictions, as well as the issue of centralisation and decentralisation by introducing the changes in two particular fields. One is the financial environment of the municipal system and the other is the direct contribution of the local authorities in public service provision. The latter is a substantial issue because, in terms of municipal capacities, it is important to present the scope left by the sectoral regulations for the local (settlement) decision makers and the extent to which they can determine the conditions of providing local public services.

regulated by act, thus the charging of taxes, the method of collecting it as well as the authority and income resources of local governance).

21 Perhaps the term decentralised Unitarian is more precise.

22 G. Soós, L. Kákai, Remarkable Success and Costly Failures. An Evaluation of Subnational Democracy in Hungary, [in:] The handbook of Subnational Democracy in the European Union, eds. J. Loughlin, F. Hendricks, A. Lindstrom, Oxford 2010, p. 528-551. 


\section{Changes in the financial environment}

After the transition, the budgetary regulation of Hungarian municipalities was built on the so-called resource regulation principle, i.e., central influence was basically asserted on the income side. Local government resources available to finance own expenditure is basically furnished by three sources: (1) revenues shared with central government (personal income tax (PIT), motor vehicle tax, duty tax, and so on), (2) own revenues (basically local taxes), (3) credits and the issuance of municipal bonds. The legislator has always tried to limit the use of the issuance of municipal bonds which is explained by the practical fact that local governments cannot go bankrupt. Since mandatory tasks (street lighting, basic health services, primary school instruction and education, and so on) must be supplied, if their level of debt makes it impossible for a local government to supply them, the state's central budget should financially substitute the local government. Until recently, loan amounts were limited to $70 \%$ of the sum of the principal own source revenues of the local government. However, this restriction was not a real limitation for local governments.

In recent years, until 2010, the measure of normative sponsoring has shown itself to be decreasing. While the measure of normative state contribution in 1991, the proportion calculated in the GFS ${ }^{23}$ system, was nearly $43 \%$ of the complete income of governments, by 2008 , it had amounted to only $16 \%$, together with normative support of defined application ${ }^{24}$.

The share of government expenses shows a continuous decrease in GDP ${ }^{25}$, even though a decrease in tasks has not taken place. Moreover, different professional (sectorial) laws were created after the Act of Government (AG) came into force and these ascertained further obligatory tasks. These laws partly include professional standards whose financing is not included in normative state contributions. The number of obligatory tasks of government has not decreased but grown. At the same time, governments are not provided with central sources proportionally to growing tasks. This has resulted in the following: the real value of government expenses has decreased by $10 \%$ in the last 13 years $^{26}$. The deterioration of the conditions of governments is well indicated by the fact that the sources

23 Government Financial Statistics.

24 The proportion of the income of governments amounted to $16 \%$ of the complete income of the governments with a view of GFS; this proportion exceeded $31 \%$ by 2008 . The greatest part within this (the proportion exceeded $54 \%$ of the incomes in the given year) is represented by local taxes (this proportion was only $15 \%$ in 1991).

25 It was approximately $18 \%$ after the change of the political system. In 2013, it has decreased to $8 \%$.

26 Ending in 2003, A. Vígvári, Politika, gazdaság és reformkényszer a helyi önkormányzati szektorban, 1990-2004, [in:] A helyi hatalom és az önkormányzati választások Magyarországon 1990-2002, ed. A. Bőhm, Budapest 2006, p. 19-65. 
of governments in real value in 2000 constituted only $49 \%$ of the sources in the year $1991^{27}$.

All in all, the data make it clear that Hungarian settlements possessed only partial autonomy since they lacked its main condition: financial independence. The above data indicate the fact that budgetary restrictions were successfully implemented in the municipal sub-system. However, the structural reforms intended to be connected to these restrictions failed again and again, owing to political resistance ${ }^{28}$. This process is clearly indicated by the financing system of local governments trying to apply the techniques of welfare systems. In addition, the whole economic policy was restrictive, especially during the government periods of 1994-1997, 1998-2000 and 2003-2004, as well as after 2006.

\section{Relations between financial and municipal (public) tasks}

Concerning municipal tasks, the Hungarian municipal system belonged to those with a wide range of responsibilities and general authority. The act on local governance passed in 1990 regulated the issues of tasks, competences and functions in its very first chapters. By local public affairs charged on the local authorities, the legislator referred to the provision of public services for the population and to the practising of power in a municipal way. Thus, the function of local authorities is clear: organising public services and practising public power (regulatory and authority) rights.

The general range of the substantial public services provided by local authorities are laid down in the act on local governance to this day. Until 2011, institution-focused public task provision was typical at Hungarian municipalities. Some of these were stipulated as obligatory tasks (although not acknowledged as civic rights), while others were described as optional or voluntary tasks. The other part of public services includes the organisational system of human public services. This set covers the institutions of public education, culture (museums, archives, cultural centres and so on), healthcare and social care.

The set of municipal tasks has in fact permanently been extended during the last twenty years ${ }^{29}$ and the prime reason for this is that the sectoral laws have the

27 Z. Lóránt, L. M. Somogyiné, A. Bukova, Az önkormányzatok költségvetési kapcsolatai 19912001 között az Állami Számvevőszék ellenőrzései tükrében, „Magyar Közigazgatás” 2002, no. 6, p. 360-370.

28 L. Kákai, Helyi és területi önkormányzatok, helyi politika, [in:] Magyar politikai rendszer - negyedszázad után, ed. A. Körösényi, Budapest 2015, p. 209.

29 According to the Report no. 0012 of 2000 of the State Audit Office of Hungary, the central government burdened 3464 functions and responsibilities on the municipalities between 1195 
right to burden obligatory tasks on local governments and to extend the content of the functions specified in the act on local governance ${ }^{30}$. As a consequence of competence regulation, the municipalities had become overloaded with obligatory tasks by 2010 , while normative supports had also been permanently changing, automatically following the changes in the regulations on task provision.

Meanwhile, duties could also be placed from the municipal side to the governmental sector without any restraint. This happened several times in terms of midlevel functions where, instead of county municipalities, decentralised state organs and institutions were given authority. Tasks were continuously transferred, several functions were moved from the municipality to the state sector (like public transport, nature and environmental protection, sports, the protection of built heritage, trade and market control, consumer protection, agricultural and land administration, and so on). In human public services, functions developed in parallel within municipal and state organs (e.g. education, pedagogical services, family care, guardian affairs or the central hospitals in healthcare, etc.) The role of the county development commissions became formal and most of their competencies in decision making "shinned up" to the regional commissions. This meant that the counties were ousted from tender calls and had no possibility to maintain infrastructure (water, sewage or waste).

The processes presented above make it clear that one of the problems of the municipal system having operated between 1990 and 2010 was system level and caused by the fact that a compound of the Northern European and the Southern European models tried to be implemented ${ }^{31}$. Namely, a fragmented settlement system was burdened with too many tasks and too high a level of service quality criteria. Our domestic municipalities were responsible for a wide range of tasks, similarly to the Northern European model which, in principle, meant that the cities with hundreds of thousands of inhabitants had almost the same rights as tiny villages with some hundreds of people. At the same time, most of the Hungarian local authorities had a low population ${ }^{32}$ like those in Southern Europe but

and 1999, which were regulated in 351 legal measures (including 133 acts), http://www.asz. hu/ASZ/jeltar.usf.

30 This practically meant that $23-27 \%$ of state expenditure was used at the local level, which meant $12-13 \%$ of the GDP, M. T. Horváth, G. Péteri, P. Vécsei, Iskolapélda a pénzügyi decentralizációról. A magyarországi helyi forrásszabályozási rendszer (1990-2012) esete, [in:] Külön utak. Közfeladatok megoldásai, ed. M. T. Horváth, Budapest-Pécs 2014, p. 337. By international comparison, this was a strong expenditure decentralisation (the average in the $27 \mathrm{EU}$ countries was $17 \%)$.

31 A. Torma, Önkormányzati reformok Nyugat-Európában és tanulságai, „Magyar Közigazgatás” 2012, no. 9, p. 513-521.

32 According to the data of 2018 by the Central Statistical Office, in $55 \%$ of the local municipalities, the population was below 1000 and was less than 5000 at 37\% (1165). All this means that in $92 \%$ of the settlements, the population was under 5000 . Source: Ministry of Finance, 
contrary to them, our domestic municipalities were in charge of a wide range of public services and the mid-level municipalities - small regions and counties were only given the "rest” of the tasks and a continuously decreasing amount of state support.

The Act on local governments, which was passed in $2011^{33}$, made considerable changes to local public service structures and municipal responsibilities. After the decentralisation experiment, the new central approach showed token strong centralisation in the spirit of a neo-Weberian ${ }^{34}$ philosophy ${ }^{35}$. The process started with the appointment of government commissioners at county level and was later completed with the creation of the new constitution, the new act on local governments, the re-tailoring of the central and local governments' task system and the reform of the finance system. The transformation of the municipal system can be taken as a local public task centralisation process implemented within a decentralised structure. The new regulatory system bringing about a strong centralisation of public service provision was closely connected to the financial consolidation of the local authorities.

After 2010, one of the elements of the changes in local governments' subsidies received from public finances was the introduction of so-called earmarked financing. This means that local governments received a part of central budgetary financing as a difference of average planned expenditure and expected revenue ${ }^{36}$. Although the shift over to labelled financing was not $100 \%$, the process meant a switch from the earlier normative financing system built mainly on unrestricted spending to a cost-oriented system of restricted spending.

In 2013, general support adjusted to the obligatory tasks of local governments was provided in the fields of municipal administration, settlement operations (street-lighting, public cemeteries, maintenance of public roads and green area management), specialist social care (institutional care) and public education ${ }^{37}$. In the cases of social, children's welfare and cultural functions, task financing was not applied. From 2014 onwards, the system of task financing was extended to children's catering as well.

https://uni-bge.hu/PSZK/Szervezeti-egysegeink/oktatasiszervezetiegysegek/PENZUGYT/dokumentumok/Kozpenzugyek/2019. Onkormanyzatok.pptx (24 I 2020).

37 A. Tállai, Egy év tükrében - Önkormányzati feladatfinanszírozás 2014 - Országos Önkormányzati és Közigazgatási Konferencia. Előadás (16 I 2014 Budapest). 
Owing to the changes in the legal regulations, larger settlements have greater authority ${ }^{38}$. The new category of "district tow” appeared; these settlements fulfil (mainly small regional public service) tasks for the whole district.

The circle of mandatory tasks of local governments in Hungary was spectacularly cut following 2010 and especially after 2014, in connection with the transformation of large public utilities and infrastructures ${ }^{39}$. To sum up the changes, in the fields of energy, water and public sewer supply, waste and settlement management, the operation of public roads and local public transport, state contribution has become dominant. As a result of competence re-organisation, the range of tasks that local governments are obliged to fulfil has considerably narrowed. This phenomenon can clearly be seen at both municipal county and settlement levels. County municipalities were deprived of all their public service functions (cultural centres, libraries, museums, archives, and so on), except for the task of regional development, which was strengthened.

Except for nursery school education, the basic tasks of public education were taken out of the set of local public affairs. In the field of cultural services, the maintenance of museums was moved from county responsibility to the settlements. Similar processes were implemented in the case of public libraries. Essential changes were made in terms of social and healthcare institutions of human public services. Except for basic social and healthcare services, all the tasks were moved under state responsibility. Previously, secondary grammar and technical schools, hostels, museums, libraries, archives, institutions providing special healthcare and elderly care homes were transferred to central authority and the belonging properties were nationalised.

In parallel with the growth in state contribution, at the turn of 2012/2013, we can see a nominal decrease of HUF 400 billion (Table 1); by filtering out the impacts of the certain regrouping, the state maintained the financing level of the remaining municipal tasks (in the average of the former year), however, for reason of the regrouping of the tasks and the general narrowing in the activity space of the local governments, they perceived this loss as bigger and unproportioned. After the governmental consolidation, municipal debt considerably decreased (almost disappeared) proportionately to the own and ceded incomes, although according to the data, it is now, at a slower pace, increasing again.

38 The model calculations made by Ilona Pálné Kovács et al. (2014) proved „the bigger the settlement, the more services provided" connection that shows bigger leaps in the population categories of 2000 and 10000 people; this picture is in line with the rules of the obligatory responsibilities allotted to local governments, [in:] Zárótanulmány a hazai önkormányzatok finanszírozási helyzetéről, ed. C. Mezei, Pécs 2014, http://docplayer.hu/5950391-Zarotanulmany-a-hazai-onkormanyzatok-finanszirozasi-helyzeterol.html (2 VI 2018).

39 Since the year 2010, in the course of the fundamental transformation of the decentralised system, the amount of tasks performed at the locality decreased by $29 \%$. 
Table 1. Local governments in the central budget 2008-2019

\begin{tabular}{|c|c|}
\hline Year & $\begin{array}{c}\text { Performance data of the section on the support } \\
\text { of local governments (HUF billion) }\end{array}$ \\
\hline 2008 & 1421716,0 \\
\hline 2009 & 1308451,9 \\
\hline 2010 & 1259386,6 \\
\hline 2011 & 1195626,5 \\
\hline 2012 & 1066707,2 \\
\hline 2013 & 674808,4 \\
\hline 2014 & 715854,9 \\
\hline 2015 & 665385,1 \\
\hline 2016 & 675415,3 \\
\hline 2017 & 641105,4 \\
\hline 2018 & 695567,3 \\
\hline 2019 & 737270,5 \\
\hline
\end{tabular}

Source: Ministry of Finance, 2019.

Covid-19 that appearing in 2020 has narrowed further the economic bases of the local governments. The first important step was the government's proposal on "special economic areas”, which would divert the investments exceeding HUF 5 milliard ${ }^{40}$ from settlement municipalities ${ }^{41}$ to county self-governments (that are currently insignificant) so that everything, from imposing taxes to renaming streets, would be taken over by the counties. As the next measure, the government has taken away vehicle tax incomes ${ }^{42}$ from the municipalities and „channelled" them into the fund established to support pandemic defence. The measure that had been meant to be temporary was included in the budget of 2021, as well, the numbers of which indicate that the government deprives this type of tax of the local governments for good. In parallel with this, next year's budget contains another important change, i.e. the increase of the municipal tax called „solidarity contribution" to the quadruple amount. So, the government improves the situation of the central budget after the corona virus in 2021 by re-allocating approximately 150 billion $\mathrm{HUF}^{43}$ at the expense of the settlement municipalities.

\footnotetext{
40 Approximately 14 million EUR.

41 Except for the cities of county rights, the capital districts and the general assembly of the capital.

42 Earlier, the government and the local municipalities had a 60:40\% share in this income.

43 Approximately 343 million EUR.
} 
As a result of the changes, the bases of the general power giving the ground of the responsibility and authority of the municipalities weakened and the principle of decentralisation and subsidiarity was strongly restricted as compared to the years before 2010 . The centralisation process resulted in very deep changes in the provision of public services for the local population - they affected much of the local public affairs.

\section{The relation of the population to change}

The act on local governance passed in 2011 transformed the local public service structures and municipal tasks considerably. The question is how the population recognised all this. What perceptions of the municipal system did they preserve? This becomes interesting, especially in light of the fact that, according to the value surveys made from the transitional era until recently, the Hungarian population tends to underestimate the costs (tax expenditure) of state intervention and expects/hopes/demands state intervention and redistribution also in terms of issues where ${ }^{44}$, in general, it would be more effective, cheaper and perhaps fairer to involve private or business resources ${ }^{45}$.

In order to research this, a population survey was ordered by the National University of Public Service. ${ }^{46}$ The program concerned the spatial optimisation of the Hungarian municipal system, the differentiation of the functions of the settlements according to their sizes, the role of the medium level and the harmonisation of governmental and municipal contribution. The survey was based on a sample of 1500 inhabitants that was representative in terms of settlement size, level of education, gender and age group ${ }^{47}$.

When we ask them what role local governments play in public services or whether tasks can be fulfilled better by the state or the municipality, in most cases, they vote for local governments (see Figure 1). Most of them think that municipalities play an important role in providing public services. They are better at fulfilling these tasks since they are aware of local needs.

${ }^{44}$ L. Csontos, J. Kornai, I. Gy Tóth, Adótudatosság és fiskális illúziók, [in:] Társadalmi Riport 1996, eds. R. Andorka, T. Kolosi, Gy. Vukovich, Budapest 1996, p. 238-271.

45 I. Gy. Tóth, A társadalmi kohézió elemei: bizalom, normakövetés, igazságosság és felelösségérzet lennének..., [in:] Társadalmi Riport 2010, eds. T. Kolosi, I. Gy Tóth, Budapest 2010, p. 254-287.

46 The research was implemented within the framework of the flagship project no. KÖFOP2.12.-VEKOP-15-2016-00001, entitled Public service development basing good governance.

47 L. Kákai, Útkereső Önkormányzatok Magyarországon, Budapest 2019. 
Figure 1. Local government or state?

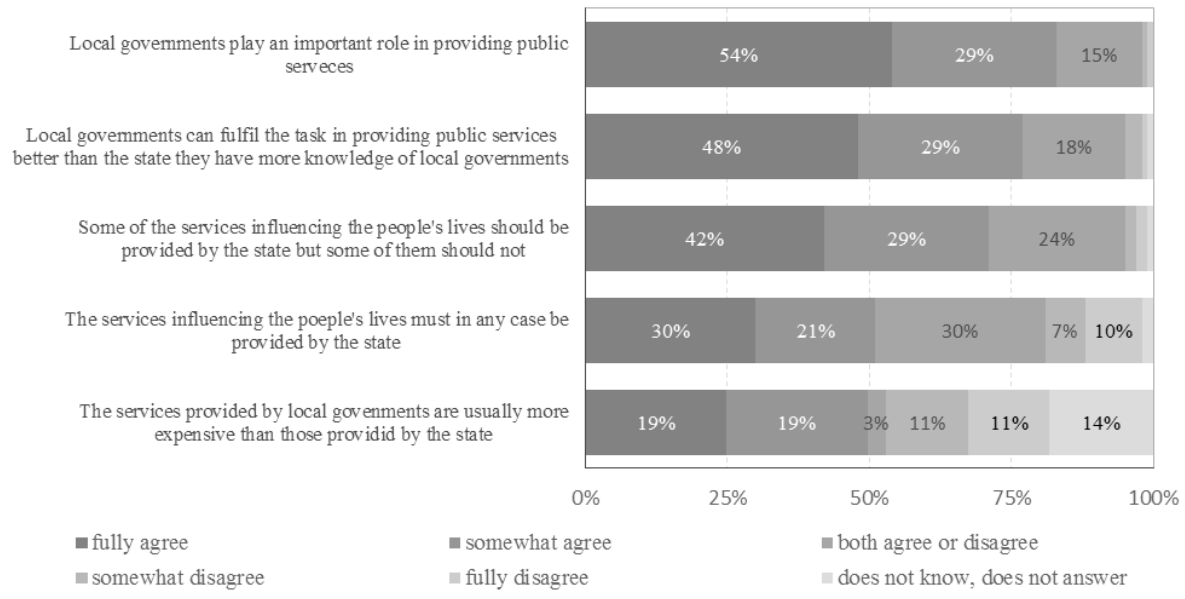

Source: Based on KÖFOP-2.12.-VEKOP-15-2016-00001 calculation by Kakai 2019.

Nevertheless, the respondents acknowledge that some tasks must be performed by the state and that responsibilities must be carefully distributed between the two agents (see Figure 2). Also, they have definite negative opinions about the over-extension of the state and the centralisation of municipal tasks.

Figure 2. Local government or state?

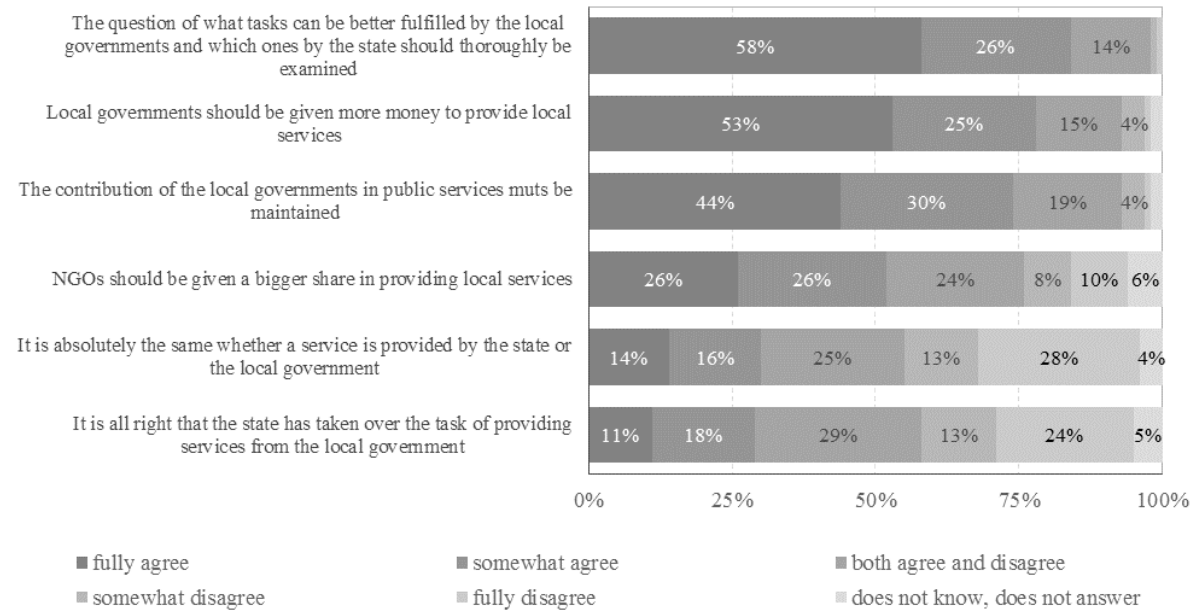

Source: Based on KÖFOP-2.12.-VEKOP-15-2016-00001 calculation by Kakai 2019. 
In case we take the opinions worded in the questions as the statements of a Likert-scale and simply summarize them ${ }^{48}$, we will see that centralization in the field of public services (so clear and strong state presence appearing everywhere) has a very small supporter base.

Regarding quality and efficiency aspects, those explicitly voting for decentralization clearly prefer local municipalities in terms of public service provision. These make 39 percent of the people asked (see Figure 3).

Figure 3. Municipality or state? - groups created by means of factor and cluster analysis

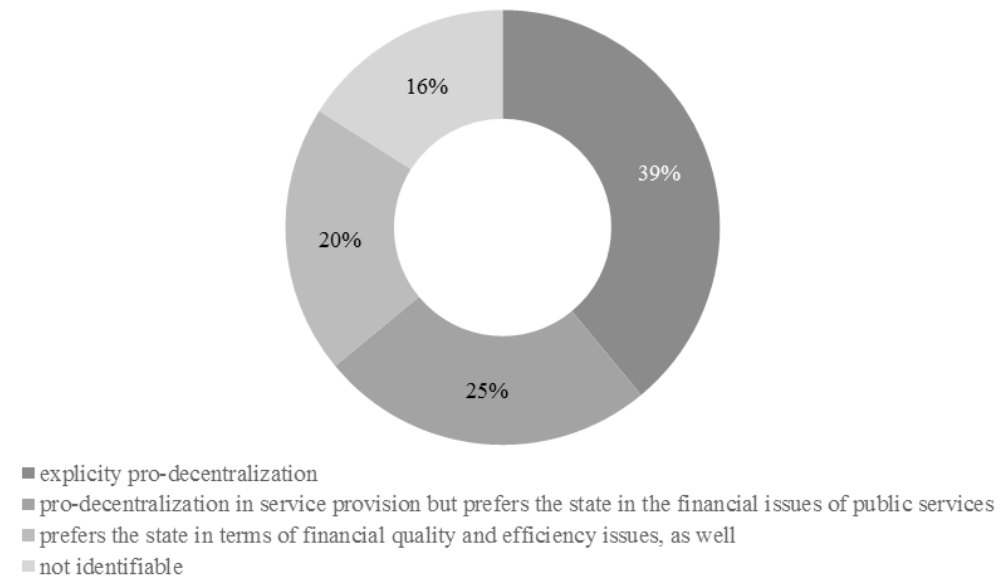

Source: Based on KÖFOP-2.12.-VEKOP-15-2016-00001 calculation by Kakai 2019.

The method of analysis divided the originally very large group of hesitant persons into several parts. One of these groups was all for decentralisation in service provision but preferred the state in terms of the financial issues of public services. This constituted 25 percent of those asked.

48 This analysis method treats the eleven statements as having equal importance, showing the primary atmosphere in connection with the examined topic. However, because of the high number of hesitant persons, it is worth investigating the finer opinion structures and interconnections hiding in the background. Doing a factor analysis, we have discovered two, clearly separated opinion dimensions behind the eleven attitude questions. The first one includes the statements examined from a quality and efficiency perspective whether it is the local government or the state that should provide local services. The second group includes the questions concerning task division from the financial and cost efficiency aspects. With the help of the two factors created this way, we were able to do a cluster analysis and examine the patterns appearing along these opinion dimensions in Hungarian society, along with the type and size of the groups characterised by these patterns. 
The other group was a pro-centralisation group that trusted the state more than any other entity in terms of the financial issues of public services and that, albeit not very strongly, also favoured the state in terms of quality and efficiency aspects. This type of thinking characterised 20 percent of those interviewed.

The answers of 16 percent were incomplete and thus impossible to categorise explicitly or did not match clearly the opinion structures of any of the groups.

One of the reasons for rejecting strong state contribution may be bad experiences. Since the law on local governments was passed in 2011 and the state withdrew tasks from the local governments, both education and healthcare have been seen in a negative light (see Figure 4). 21 percent think that the circumstances have declined since the organisation of primary and secondary level education were taken over by the state and the majority thinks conditions have remained the same (which, with regard to the long-lasting negative judgement of education, is also problematic). Only 13 percent think there has been any improvement. The changes having taken place in the operation of hospitals have been judged even worse. Here, 40 percent think that conditions have definitely declined since 2011 . Forty three percent think that there have been no changes, which is also problematic regarding the fact that healthcare had already long been judged as rather poor.

The only field where the balance of changes is somewhat positive is public administration. Here, 35 percent see improvements but the absolute majority of respondents (54 percent) still see unchanged conditions in this field (see Figure 4).

Figure 4. Since 1 January, 2013, ... have been operated by the state. Have you experienced any changes in everyday life?

Since $1^{\text {st }}$ January 2013, primary and secondary schools have been operated by the state. Have you experience any changes in the everyday life of the school?

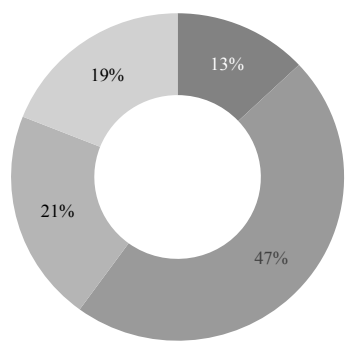

- circumstances have improved

- there have been no changes

n circumstances have declined

a does not know, does not answer
Since $1^{\text {st }}$ January 2013, the hospitals have been maintained by the state. Have you experience any changes in daily health care?

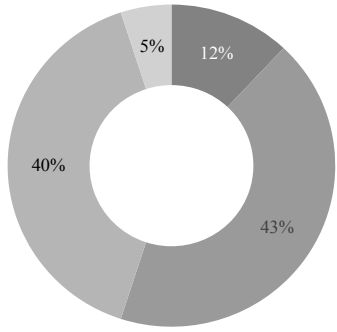

a circumstances have improved

- there have been no changes

n circumstances have daclined

in does not know, does not answer
Since 1st January 2013, the spots of public administration have been re-organized. Have you experience any changes in everyday management of affairs?

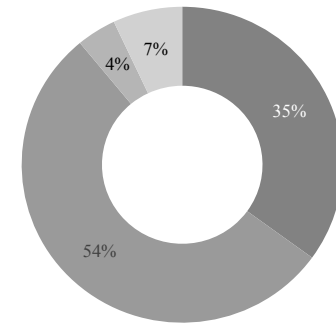

- circumstances have improved - there have been no changes ar circumstances have declined w does not know, does not answer 
The negative experiences from the past give a clear explanation of why people reject further extensions of the state withdrawing functions from local governments (see Figure 5).

Figure 5. The transformation of the role of local governments is a popular topic these days. In your opinion, if local governments did not play any role in the fields listed below, would their quality be better, worse or the same as it is today?

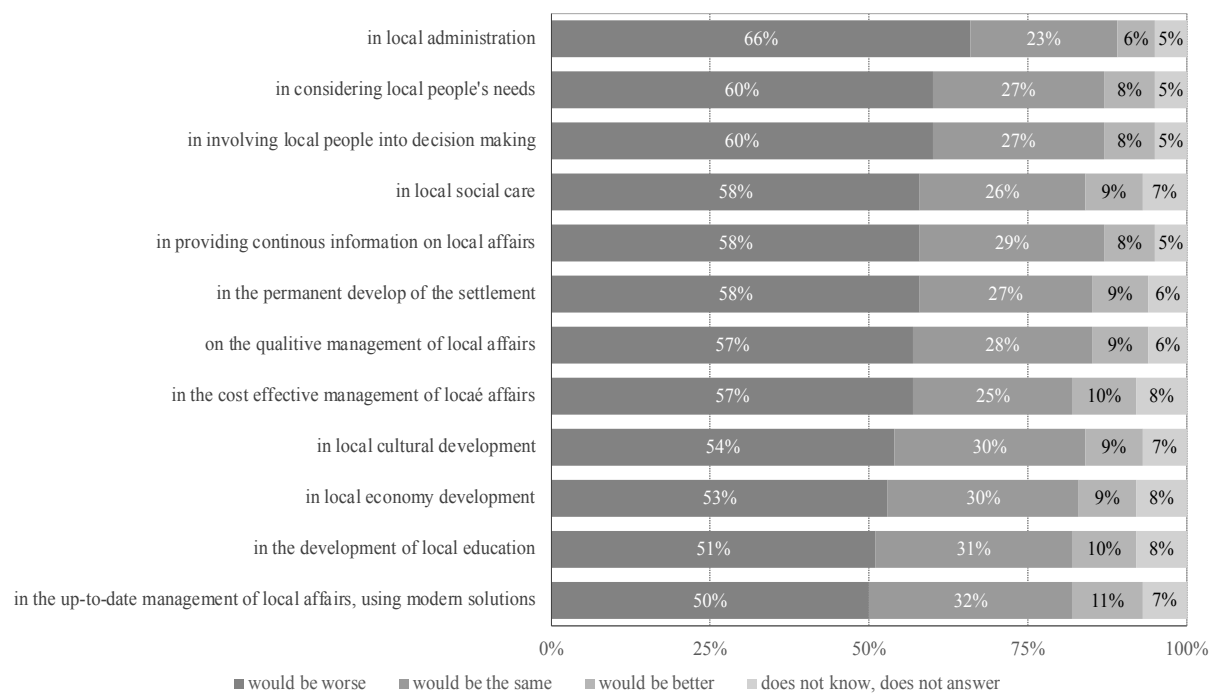

Source: Based on KÖFOP-2.12.-VEKOP-15-2016-00001 calculation by Kakai 2019

When we asked people how the quality of the given service would change if local governments had no authority in public services, we were met overwhelmingly with negative opinions.

Those envisioning decline had absolute majority in each field. Only an insignificant portion thought improvement was possible.

Further centralisation is definitely seen in a bad light; the majority of the respondents thought that if the state took over the management of a certain field, the quality of related services would decline.

By means of factor analysis, we also tried to identify some latent structure in the attitudes concerning the twelve opinions in terms of this question. This, however, was not possible since all twelve aspects appeared in the analysis as belonging to the same dimension. 


\section{Conclusion}

It is difficult to give a proper answer to the question of what the optimal ratio of centralisation and decentralisation would be ${ }^{49}$ since the state provides some control over the economy, intervenes in the economy to some extent, provides free services and implements some redistribution in each field ${ }^{50}$. Therefore, disagreements and conflicts evolve at each of the "contact points" of the various sub-systems within the state.

Centralisation tendency was a tried and tested practice of managing the economic crisis of 2008 across Europe. In several countries, considerable restrictions and the reorganisation of competences took place. In this respect, Hungary does not differ from other European countries. Thus, concerning the issue of centralization vs. decentralisation, no clear standpoint can be taken. The successfulness of one or another governmental structure depends on several factors, ranging from the economic, social, political and cultural context of the given country to the interpretation of the two governmental structures in that country ${ }^{51}$. However, we have to point out the fact that the deep and very rapid transformation of the municipal system was not only a manifestation of the constraints caused by the economic crisis in Hungary, but a process carefully prepared by the government in line with international regulations. The basic law passed by a majority of two-thirds and the new act on local governments are both parts of a consequent political process in which the state takes the municipalities as the executors of the government's policy. Thus, their scope of activity, budget and public service functions are connected to the state more tightly.

The government gave a specific response to the problems having pressed the municipal system since 1990. The response was undoubtedly the significant reduction of municipal autonomy and the strengthening of state competences. With these changes, the government also gave an answer to the question of centralisation and decentralisation that had been present since the transition, to the advantage of the previous one. It also weakened the possibility of the awakening of a possible municipal "counterbalance” by ordering a great part of the municipal responsibilities under the central government's authority and by strengthening control over the economic operation of local governments. The municipal reform directed from above was implemented basically without any considerable opposition from society or municipal associations. The data of the survey introduced in the study make it clear that local population had little information

49 K. I. Pálné, Helyi kormányzás Magyarországon, Budapest-Pécs 2008.

50 J. Kornai, Látlelet. Tanulmányok a magyar állapotokról, Budapest 2017, p. 71.

51 J. Litvack, J. Ahmad, R. Bird, Rethinking Decentralization in Developing Countries, World Bank. Sector Studies Series, Washington DC 1998. 
about the changes and their directions and impacts on local life circumstances. Therefore, we cannot undoubtedly state that local people are not affected by the transformation of the municipal system and that it is of no importance to them who the local service provider is since, as we can see, they think the presence of local authority is important in many fields. That said, we also cannot say with certainty that local population takes municipal autonomy ",under its wings". At the same time, it is clear that the population is sceptical in terms of governmental centralisation and the philosophy of the strong state willing to solve everything. According to the surveys, they do not think that the state can manage the tasks and services withdrawn from the local level any better than municipalities can. So far, we have no proof of the presumption that the centralisation of the financing and management of a wide range of public services has resulted in more effective and higher quality services ${ }^{52}$. In the light of the results it cannot be proven that transformation brings about a higher standard of services or higher level of content (the data rather show a general decline). At the same time, we cannot conclude that the centralizer itself can be declared ,impetuous” or, in terms of its objectives, „irrational” or „mistaken” ${ }^{3}$.

\section{Abstract \\ László Kákai \\ Trailing back from quasi decentralisation to centralisation. Municipal reform in Hungary}

It is very difficult to group countries and state structures according to the extent of their decentralization or the model they follow in the spatial distribution of power. The bounds of responsibility of local government and the state, the distribution of the roles and tasks between the two stakeholders and the question of centralization and decentralization are issues regularly debated in recent years and today.

This topic is not merely a public administration, financial or state organization issue since these decisions have a direct impact on citizens' lives through public services.

52 L. Kákai, B. Vető, Állam vagy/és önkormányzat? Adalékok az önkormányzati rendszer átalakításához, „Politikatudományi Szemle” 2019, no. 1, p. 17-41.

53 P. Bordás, I. Bartha, M. T. Horváth, Jobban teljesít. Centralizáció és minőség, „Politikatudományi Szemle" 2020, no. 1, p. 93. 
In my study I wish to introduce this process via Hungary's example. I also examine how and what those concerned by the financial and political changes, i.e. the population perceived of this most important structural transformation of the period since the transition in 1989. Can it be verified from the consumers' point of view that the transformation of the local municipal system improves the quality of service provision?

Keywords: local government, centralization, decentralization, local governments finances. local public services, Hungary

\section{References}

Bordás, P., Bartha I., Horváth, M. T., Jobban teljesit. Centralizáció és minőség, „Politikatudományi Szemle” 2020, no. 1, p. 73-96.

Csontos, L., Kornai, J., Tóth, I. Gy., Adótudatosság és fiskális illúziók, [in:] Társadalmi Riport 1996, eds. R. Andorka, T. Kolosi, Gy. Vukovich, Budapest 1996, p. 238-271.

Dahl, R., Who Governs? Democracy and Power in an American City, New Haven 1961.

Dearlove, J., The Reorganisation of British Local Government, Cambridge 1979.

Dreschler, W., Kattel, R., Towards the Neo-Weberian State? Perhaps, but Certainly Adieu, NPM!, „The NISPAcee Journal of Public Administration and Policy” 2009, no. 2, p. 95-101.

Dunleavy, P., Urban Political Analysis, London 1980.

Finta, I., A helyi-területi szintü közigazgatási szervezetek gazdaságirányítási, támogatás-fejlesztési funkcióinak jogszabályi háttere, [in:] Versenyképesség és igazgatás (tanulmányok a regionális versenyképesség igazgatási feltételeiről, ed. I. K. Pálné, Pécs 2004, p. 35-56.

Hajdú, Z., A magyar megyerendszer történeti, területi fejlödésének sajátosságai, [in:] A rendszerváltás és a megyék, eds. Z. Agg, I. K. Pálné, Veszprém 1994, p. 7-29. Handbook of Public Policy, eds. G. B. Peters, J. Pierre, London 2006.

Local Government and Urban Affairs in International Perspective, ed. J. J. Hesse, Baden-Baden 1991.

Horváth, M. T., Péteri, G., Vécsei, P., Iskolapélda a pénzügyi decentralizációról. A magyarországi helyi forrásszabályozási rendszer (1990-2012) esete, [in:] Külön utak. Közfeladatok megoldásai, ed. M. T. Horváth, Budapest-Pécs 2014, p. 331-353.

Kádár, K., Reformkonyha a magyar közigazgatásban, [in:] A közigazgatási reform új perspektívái, ed. A. Ágh, I. Somogyvári, Budapest 2006, p. 296-319. 
Kákai, L., Kik vagyunk mi? Civil szervezetek Magyarországon, Pécs 2009.

Kákai, L., Önkormányzat és lakosság viszonya, avagy bizalom vagy bizalmatlanság, [in:] Közigazgatás és az emberek, ed. F. Csefkó, Pécsi Közigazgatás-Tudományi Közlemények 5. A Jövő Közigazgatásáért Alapítvány, Pécs 2013, p. 153-170.

Kákai, L., Helyi és területi önkormányzatok, helyi politika, [in:] Magyar politikai rendszer - negyedszázad után, ed. A. Körösényi, Budapest 2015.

Kákai, L., Vető, B., Állam vagy/és önkormányzat? Adalékok az önkormányzati rendszer átalakitásához, „Politikatudományi Szemle” 2019, no. 1, p. 17-41.

Kákai, L., Útkereső Önkormányzatok Magyarországon, Budapest 2019.

Kornai, J., Látlelet. Tanulmányok a magyar állapotokról, Budapest 2017.

Litvack, J., Ahmad, J., Bird, R., Rethinking Decentralization in Developing Countries, World Bank. Sector Studies Series, Washington DC 1998.

Loughlin, J., Subnational Democracy in the European Union. Challenges and Opportunities, Oxford 2001.

Lóránt, Z., Somogyiné, L. M., Bukova, A., Az önkormányzatok költségvetési kapcsolatai 1991-2001 között az Állami Számvevőszék ellenörzései tükrében, „Magyar Közigazgatás" 2002, no. 6, p. 360-370.

Musgrave, R. A., The Theory of Public Finance. New York 1959.

Oates, W. E., Toward a second-generations theory of fiscal federalism, „International Tax and Public Finance" 2005, no. 12, p. 349-373.

Pálné, K. I., Helyi kormányzás Magyarországon, Budapest-Pécs 2008.

Saunders, P., Urban Politics: A Sociological Interpretation, Harmondsworth, 1980.

Soós, G., Kákai, L., Remarkable Success and Costly Failures. An Evaluation of Subnational Democracy in Hungary, [in:] The handbook of Subnational Democracy in the European Union, ed. J. Loughlin, F. Hendricks, A. Lindstrom, Oxford 2010, p. 528-551.

Szalai, Á., Fiskális Föderalizmus. Áttekintés, „Közgazdasági Szemle” 2002, no. 5.

Tállai, A., Egy év tükrében - Önkormányzati feladatfinanszírozás 2014 - Országos Önkormányzati és Közigazgatási Konferencia. Előadás. (Budapest, 2014. január 16.).

Tiebout, Ch. M., A pure theory of fiscal decentralization, „The Journal of Political Economy" 1956, no. 64. p. 416-424.

Torma, A., Önkormányzati reformok Nyugat-Európában és tanulságaik, „Magyar Közigazgatás" 2012, no. 9, p. 513-521.

Tóth, I. Gy., A társadalmi kohézió elemei: bizalom, normakövetés, igazságosság és felelösségérzet - lennének..., [in:] Társadalmi Riport 2010, eds. T. Kolosi, I. Gy. Tóth, Budapest 2010, p. 254-287.

Weingast, B. R., Second generation fiscal federalism: Implications for decentralised democratic governance and economic development, Discussion Draft, Hoover Institution, Stanford 2009. 
Vígvári, A., Politika, gazdaság és reformkényszer a helyi önkormányzati szektorban, 1990-2004, [in:] A helyi hatalom és az önkormányzati választások Magyarországon 1990-2002, ed. A. Bőhm, Budapest 2006, p. 19-65.

Vígvári, A., Atipikus önkormányzati eladósodás Magyarországon, „Közgazdasági Szemle" 2009, no. 7-8, p. 709-730.

Zárótanulmány a hazai önkormányzatok finanszírozási helyzetéröl, ed. C. Mezei, Pécs 2014.

László Kákai - prof. politologii, kierownik Katedry Nauk Politycznych i Stosunków Międzynarodowych na Wydziale Nauk Humanistycznych i Społecznych Uniwersytetu w Peczu. ORCID: 0000-0002-0380-4309 